\title{
PEMAHAMAN JIHAD \\ KA LANG AN SI SWA TERN ATE \\ Puritanisme tanpa Kekerasan
}

\author{
Oleh: Abd. Kadir Ahmad
}

\begin{abstract}
This research aims to describe student of high school perspective on Jihad. This research was conducted at three high schools in Ternate and two high schools in Makassar. Data was collected using questioner to among 212 students of five high schools, and analyzed using quantitative method.

The result of study indicates that (1) students of high school understood Jihad as struggling, sacrifice, war, and death as martyr; (2) this perspective of Jihad was influenced by social construction; (3) Although their perspective tend to purity, but they reject the radicalism of religion as solution.
\end{abstract}

Key words: student, perspective, Jihad.

\section{PENDAHULUAN}

$\mathrm{T}$

lidak ada satu aspek dari agama Islam yang akhir-akhir ini mendapat porsi besar di mata publik dan berbagai media selain jihad. Hal itu, antara lain, disebabkan oleh berkembangnya klaim yang menyemangati berbagai aksi teror yang melibatkan person-person orang Islam, atas landasan jihad. Padahal sesungguhnya, menurut El-Fadl, jihad dalam Islam merupakan fondasi berbagai kemampuan Islam untuk hidup berdampingan secara damai dan bekerjasama dengan non-Muslim.' Meskipun telah banyak tulisan mengenai topikjihad, apa yang menjadi pertanyaan pokok adalah bagaimana begitubanyak kalangan Islam yang memahaminya secara berbeda. Selain karena pemahaman

Jurnal -'Al-Qalam'" No. XXII Tahun XIV Edisi Juli - Desember 2008 
yang dangkal, kontroversi pemaknaanjihadjuga karena pernyataan-pernyataan dan bahkan kelakukan sebagian orang Islam telah menjadikan konsepjihad semakin membingungkan dan simpang siur, terutama pada era modem sekarang ini. Seperti diakui El Fadl, jihad, sebagaimana banyak dilangsir media Barat dan yang telah dieksploitasi kelompok ekstrim, seringdikaitkan dengan ide tentang perang suci, yang dikobarkan atas naraa Tuhan, terhadap orang kafir dan kerap disamakan dengan sikap tidak toleran dalam beragama. Di atas segalanya, isu terorisme telah mencemarkan reputasi agama terbesar kedua di dunia tersebut. ${ }^{2}$

Isu yang berkembang sekitar pemaknaan jihad dan implikasinya dalam kehidupan telah membedakan posisi kelompok moderat dan puritan di kalangan umat Islam, seakan dim dunia berbeda. Masalahnya terletak pada kenyataan bahwa kalangan puritan berbicara lebih keras daripada kalangan moderat. $\mathrm{Pu}-$ ritan tidak mengharamkan berbicara dengan senjata, sementara senjata apa yang dimiliki kolompok moderat untuk berbicara?

Jika pemaknaan terhadap j ihad telah sampai pada pembelahan antara kelompok moderat dan puritan dalam masyarakat, maka dimanakah posisi segmen masyarakat yang sedang belajar di bangku sekolah? Bagaimanakah mereka memberikan makna terhadap jihad? Hal ini penting dipertanyakan, sebab secara politis, pendidikan agama di sekolah di Indonesia, mendapat legitimasi cukup kuat dalam sistem pendidikan nasional. Secara sosiologis siswa sekolah merupakan generasi yang dalam perkembangannya tidak terlepas dari sosialisasi nilai dan cara hidup dari mereka yang lebih tua di dalam masyarakat. Dalam konteks ini, pemaknaan jihad dan implikasinya dalam interaksi sosial merupakan satu di antara konsep-konsep yang diduga telah membentuk pola pikir siswa. Penelitian tentang pemaknaan jihad di kalangan siswa, mendapat legitimasi dari cara pandang seperti ini. Penelitian ini dikemas dalam satu paket penelitian bertajuk Pola Keberagamaan Siswa, membuat substansinya lebih luas dari sekedar pertanyaan tentangjihad. Untuk kepentingan tulisan ini, penulis hanyamengangkat tenia jihad, sesuatu yang cukup relevan dengan kondisi terakhir di negeri ini, bersamaan dengan semakin menajamnya polarisasi pemaknaan tersebut, terutama menyusul eksekusi mati Amrozi dan kawan-kawan di depan regu tembak, yang dieksekusi mati (hari Minggu, tanggal 9 November 2008,jam 00.15) di Nusakambangan, meski penelitian itu sendiri sudah dilakukan jauh hari sebelumnya, yakni Bulan Agustus 2008.

Ketua Majelis Ulama Indonesia KH.Ma'ruf Amin, misalnya, menegaskan bahwa Amrozi, Imam Samudra, dan AliGufron alias Mukhlas bukan mati syahid. Menurutnya, perjuangan Amrozi CS dengan teror bukan cara yang tepat dalam perjuangan Islam. Perjuangan dalam Islam pada masa damai dilakukan dengan 
dakwah. Kecuali di daerah perang. Indonesia (saat peristiwa bom Bali dan sekarang) tidak sedang dalam perang. ${ }^{3}$ Sebelum dieksekusi, Imam Samudra menulis surat vvasiat untuk dibacakan kepada publik. Isinya, antara lain, menyebutkan gelar teroris lebih mulia daripada ulama yang tidak peduli pada saudarayangdibunuhorangkafir. 'Paraulamamenilai itutidaktepat,ujarMa'ruf Amin, seperti ditulis Tempo. Pendapat senada diutarakan Ketua Umum Pengurus Besar Nahdlatul Wathan Tuan Guru Bajang KH Muhammad Zainul Madjdi. Menurut dia, mujahid adalah orang yang memiliki dedikasi tinggi dan penuh tanggung jawab pada masyarakat. Termasuk jauh dari pikiran ekstrimitas. Menurutnya, cara Amrozi CS melawan Amerika Serikat tidaklah tepat. Seharusnya protes terhadap AS dilakukan di negeri adidaya itu, bukan di Indonesia. Perjuangan yang benar bukan menggunakan senjata dan tidak boleh menyakiti. Islam, katanya, tidak pernah ada masalah dengan kemajemukan di kalangan masyarakat.

Hal ini berbeda dengan pendapat Abu Bakar Ba'asyir. Di Lamongan, sebelum jenazah Amrozi diberangkatkan ke pemakaman, mantan pimpinan Majelis Mujahidin Indonesia itu, mengaku sangat bangga pada Amrozi, Muklas, dan Imam Samudra yang dia anggap mati syahid. ${ }^{4}$ Konsep mati syahid secara teologis dipahami sebagai status yang pantas diterima oleh seseorang yang meninggal karenaberjihad dijalan Allah atau mujahid.

Penelitian ini dilakukan di Ternate, kota tua dan dikenal di manca negara sejak dulu berkat posisinya sebagai pusat perdagangan cengkeh dan pala. Ternate berpenduduk 170.776 jiwa, sebanyak 36.234 orang di antaranya adalah siswa dari tingkat SD sampai SLTA.Ternate pernah mengalami kerusuhan yang melibatkan umat beragama tahun 1999, yang menyebabkan terjadinya perubahan struktur sosial, khususnya di bidang kependudukan. ${ }^{3}$

Masalah pokok penelitian ini adalah bagaimana pemaknaan yang diberikan oleh siswa mengenai jihad? Apakah pemaknaan jihad tersebut terkait dengan pemahaman tentang kekerasan atas nama agama?Dengan demikian, penelitian ini bertujuan memahami bagaimana siswa mengonstruksi pemahaman tentang $\mathrm{j}$ ihad termasuk pandangan mereka terhadap tindak kekerasan atas nama agama.

Penelitian ini memilih sampel pada lima Sekolah Menengah Atas Negeri di Ternate dan Makassaryang diklasifikasikan ke dalam sekolah unggulan, sekolah favorit dan sekolah biasa. Berdasar kriteria tersebut, terpilih 3 sekolah SMA Negeri di Ternate dan 2 sekolah setingkat di Makassar. Jumlah siswa yang terjaring sebagai sampel adalah 121 orang di Ternate dan 91 siswa di Makassar. 


\section{Abd. Kadir Ahmad}

Setidaknya, terdapat 36 persen orang tua siswa berasal dari kalangan PNS, 31 persen dari kalangan wiraswasta, dan selebihnya (22 persen) petani atau nelayan. Hanya 8 persen orang tua siswa berpendidikan setingkat SD, 15 persen berpendidikan setingkat SLTP dan 57 persen lainnya SLTA. menyusul SI 19 persen. Bahkan terdapat sejumlah orang tua (4 persen) berlatar belakang S2 dan S3. Anak-anak sekolah unggulan selain memiliki orang tua berlatar belakang PNS dan wiraswastajuga dari kalangan orang tua yang pendidikannya lebih tinggi, yaitu 14 persen berpendidikan SI dan S2. Sebaliknya, tingkat pendidikan orang tua lebih rendah tergambar pada sekolah biasa sampai favorit. Semua siswa dari orang tua berpendidikan S1 ke atas memilih IPA.

Analisis data dilakukan dengan menggunakan frekuensi dan korelasi Spearman untuk melihat adanya hubungan antara satu variabel dengan variabel lain. Sedangkan data kualitatif dianalisis dengan pendekatan semiotik yang memberikan tempat sentral pada tanda. Sebagai ilmu yang mengkaji tanda, semiotik juga melihat tanda sebagai gejala budaya. Semiotik melihat kebudayaan sebagaai suatu sistempemaknaan. Bahkan maknatanda adalah hasil suatu konvensi, suatu prinsip dalam kehidupan berkebudayaan. Kalaupun yang diteliti itu suatu teks atau ungkapan bahasa, maka iapun dilihat sebagai tanda.

\section{KONSTRUKSI JIHAD}

Dengan menggunakan bahasa sebagai tanda dari apa yang diinginkan atau dimaksudkan, ternyata siswa kebanyakan merepresentasikan makna jihad lewat konsep berperang, berjuang, membela, berkorban sampai kepada yang paling netral, berusaha. Konsep berperang menempati tingkat paling tinggi dari hirarki ekstrimitas yang diwakilkan oleh pemaknaan jihad.

Pemaknaan dengan berjuang menempati urutan tertinggi dengan redaksi yang bervariasi tetap dengan makna relatif sama. Di bawah ini pemaknaan yang diberikan siswa dengan menggunakan konsep berjuang.

\section{Jihad sebagai Perjuangan}

Di bawah ini ditampilkan konstruksi jihad bagi siswa yang terkait dengan konsepjihad sebagai sebuah perjuangan. Hal ini terutama dengan penggunaan bahasa atau kata berjuang sebagai tanda. 
Tebel 1 : Pemaknaan Jihad sebagai Perjuangan

\begin{tabular}{|c|c|}
\hline NO & KONSTRUKSIMAKNA JIHAD \\
\hline 1 & Berjuang untuk mempertaliankan kebenaran di jalan Alah dan membela agama \\
\hline 2 & Berjuang di jalan Allah, rela berkorban \\
\hline 3 & Berjuang dengan bersungguh-sungguh terhadap apa yang benar sesuai syariat Islam \\
\hline 4 & Berjuang membela agama diajarkan Allah agar mendapat rida Allah \\
\hline 5 & Berjuang di jalan Allah membelaagama \\
\hline 6 & Berjuang di jalan yang benar, yaitu di jalan Allah \\
\hline 7 & Berjuang mempertahankan agama Islam \\
\hline 8 & Berjuang membela agama \\
\hline 9 & Berjuang menegakkan agama Allah walaupun nyawa sebagai taruhan \\
\hline 10 & Berjuang menegakkan agama Allah \\
\hline 11 & $\begin{array}{l}\text { Berjuang di jalan yang benar dalam bentuk apa pun juga yang penti-ng kita melakukannya } \\
\text { dengan ikhlas sematamata karena Allah }\end{array}$ \\
\hline 12 & $\begin{array}{l}\text { Berjuang demi agama Islam di jalan Allah dengan niat ikhlas hanya untuk mempertahankan } \\
\text { agamanya }\end{array}$ \\
\hline 13 & Berjuang, membela agama Allah (Islam) sampai titik darah penghabisan \\
\hline 14 & Berjuang di medan perang untuk membela agama Allah dan semata-mata hanya untuk Allah \\
\hline 15 & Berjuang di jalan Allah, atau membela agama Allah SWT, jangan peduli nasib dirinya \\
\hline 16 & Perjuangan (perang suci) untuk membela agama di jalan Allah \\
\hline 17 & Memperjuangkan islam dan rela mati un diperjuangkan \\
\hline 18 & Berjuang menegakkan kalimat Allah \\
\hline 19 & Memperjuangkan agama Allah tanpa pamrih dan mengharap rida Allah \\
\hline 20 & Memperjuangkan nama Allah di jalan-Nya \\
\hline 21 & Berjuang di jalan Allah \\
\hline 22 & Berjuang mempertahankan agama Allah \\
\hline 23 & Memperjuangkan kalimat Allah \\
\hline 24 & Memperjuangkan ajaran agama Islam \\
\hline 25 & Memperjuangkan agama Allah di jalan yang diredhai Allah \\
\hline 26 & Memperjuangkan ajaran dan agama Islam semata-mata karena in gin mendapat rida Allah \\
\hline 27 & Berjuang di jalan Allah atau membela agama Allah (Islam ) dari kaum Yahudi \\
\hline
\end{tabular}

Berjuang, memperjuangkan, dan perjuangan menjadi kata kunci yang pada umumnya mengontruksi ide siswa tentang jihad. Hal ini mendapatkan kesan kuat seakan tidak ada medan jihad tanpa perjuangan. Perjuangan yang dimaksud bervariasi ber poros pada berjuang : dijalan Allah, agama Islam, agama, ajaran Islam, kalimat Allah, agama Allah, Islam, sampai kepada yang lebih umum berjuang di jalan yang benar. Berjuang itu sendiri pada dasarnya berarti berlaga, berlawan, memperebutkan sesuatu dengan mengadu tenaga, berperang, berkelahi, dan berusaha sekuat tenaga tentang sesuatu, berusaha penuh dengan kesukaran dan bahaya.' Makna jihad dengan representasi tanda berjuang, memperjuangkan, atau perjuangan, dengan demikian, bergerak antara keharusan berperang dijalan Allah dan berusaha sekuat tenaga untuk mencapai sesuatu di jalan Allah. Namun demikian, dalam konteks konstruksi siswa 
mengenai hal ini, kecenderungan ke arah makna yang pertama lebih kuat. Selain dapat terlihat dari pengungkapan kalimat-kalimat dalam tabel, juga akan tampakjelas pada penguatan makna tersebut dengan konstruksi maknajihad lewat tanda (kata) berperang. Dalam tabel terlihat perjuangan paling ekstrim adalah berjuang sampai titik darah penghabisan, tanpa mempedulikan nasib sendiri, walaupun nyawa sebagai taruhan, rela mati. Sementara perjuangan yang lebih luas adalah memperjuangkan agama Allah di jalan yang diredhai Allah, tanpa pamrih, dan niat ikhlas. Berjuang melawan siapa, tidak disebutkan secara spesifik, kecuali ada siswa yang menyebut Yahudi. Dengan demikian pemaknaannya bisa siapa atau kelompok apa saja.

\section{Jihad sebagai Perang}

Siswa memaknai jihad dengan berperang lebih menspesifikkan makna berjuang daripada maknanya yang lain. Hal ini diungkapkan melalui frasa : melakukan perang, memerangi, perang suci, berperang. Dalam Kamus Besar Bahasa Indonesia berperang diartikan permusuhan antara dua negara (bangsa, agama, suku, dsb.); pertempuran besar bersenjata antara dua pasukan atau lebih; perkelahian; cara mengungkapkan permusuhan. Berikut ini siswa mengungkapkan maknajihad dengan tanda perang dalam konstruksi kalimat beragam.

Tabel 2 : Pemaknaan Jihad sebagai Perang

\begin{tabular}{|c|l|}
\hline NO & \multicolumn{1}{|c|}{ KONSTRUKSI MAKNA JIHAD } \\
\hline 1 & Melakukan perang untuk membela agama Islam dengan hati ikhlas \\
\hline 2 & $\begin{array}{l}\text { Mengarahkan segala kemampuan dan tenaga untuk memerangi orang -orang kafir dengan } \\
\text { tujuan mengharapkan ridha Allah SWT dan meninggikan kalimatnya }\end{array}$ \\
\hline 3 & Perang suci memerangi orang kafir unrak membela agama Islam \\
\hline 4 & $\begin{array}{l}\text { Berjihad di jalan Allah yaitu untuk membela/berperang demi membela agama Islam biar } \\
\text { nyawa taruhannya mereka tetap membela agama mereka sendiri }\end{array}$ \\
\hline 5 & Berperang di jalan untuk membela agama Islam \\
\hline 6 & Berperang di jalan Allah dan apabila orang tersebut mati, orang tersebut disebut mati syahid \\
\hline 7 & Memerangi suatu kaumyangzalim, berj uang menegakkan agama Islam dalam segala hal \\
\hline 8 & Berperang untuk membela agama Allah dan semata hanya untuk Allah \\
\hline 9 & $\begin{array}{l}\text { Perang suci memerangi orang kafir untuk membela agama Islam dan perang di jalan Allah } \\
\text { SWT }\end{array}$ \\
\hline 10 & Berperang di jalan Allah demi membela agama Islam \\
\hline 11 & $\begin{array}{l}\text { Perang suci memerangi orang kafir untuk membela agama Islam dan perang di jalan Allah } \\
\text { SWT }\end{array}$ \\
\hline 12 & $\begin{array}{l}\text { Mengorbankan jiwa dan raga, memerangi orang kafir, untuk membela agama Allah, yakni } \\
\text { Islam }\end{array}$ \\
\hline 13 & Perang di jalan Allah \\
\hline 14 & Perang suci memerangi orang kafir untuk membela agama Islam \\
\hline 15 & Melakukan perjalanan atau pertempuran semata-mata untuk Allah \\
\hline 16 & Berperang membela Islam bertujuan membuat perdanian \\
\hline 17 & Menegakkan syariat Islam dan melawan orang yang menghancurkan Islam \\
\hline
\end{tabular}


Berbeda dengan berjuang yang konteksnya dapat berupa perang dan dapat pula berarti usaha sekuat tenaga untuk mencapai sesuatu dalam suatu kondisi penuh resiko, maka perang jelas bermakna perlawanan dan konfrontasi terhadap pihak lain. Bahkan dalam pernyataan siswa berupa pertempuran. Dengan siapa perang harus dilakukan ? Tanda-tanda tersebut menyebutkan secara umum perang diarahkan kepada siapa saja yang ingin menghancurkan Islam dan kaum zalim. Kalau ini yang terjadi, maka konteksnya bisa orang Islam itu send iri yang oleh kelompok yang berkepentingan dipandang akan menghancurkan Islam atau kelompok lain di luar Islam, orang kafir. Dalam realitas komunitas Islam berhaluan keras, perang bisa saja diarahkan pada sesama pemeluk agamayang dianggap sesat. Konsekuensi berperang dijalan Allah diganjardengan mati syahid, kalau yang bersangkutan gugur di dalam aksi tersebut.

\section{Jihad sebagai Pengorbanan}

Konsekuensi dari perjuangan dan bahkan perang ditandai dengan pengorbanan. Siswa memaknai jihad, dengan demikian, dengan keharusan berkorban atau pengorbanan. Kata yang digunakan sebagai tanda adalah berkorban, mengorbankan, dalam konteks rumusan kalimat yang bervariasi.

Tabel 3 : Pemaknaan Jihad sebagai Pengorbanan

\begin{tabular}{|c|l|}
\hline NO & \multicolumn{1}{|c|}{ KONSTRUKSIMAKNA JIHAD } \\
\hline 1 & Mengorbankan nyawa seseoran g derri kcpeptingan di jalan Allah \\
\hline 2 & $\begin{array}{l}\text { Rela berkorban demi membela apa saja. walaupun harus mati atau hidup. yang penting di } \\
\text { jalan yang benar (di jalan Allah) }\end{array}$ \\
\hline 3 & $\begin{array}{l}\text { Mengorbankan jiwa dan raga. memerangi orang kafir. untuk membela agama Allah, yakni } \\
\text { Islam }\end{array}$ \\
\hline 4 & Rela berkorban di jalan Allah \\
\hline 5 & Mengorbankan segala sesuatu untuk Allah, membela kebaikan \\
\hline 6 & $\begin{array}{l}\text { Rela mengorbankan hart a. keluarga bahkan jiwa sckaligus untuk mempenahankan dan } \\
\text { membela asama Allah. }\end{array}$ \\
\hline
\end{tabular}

Materi pengorbanan dapat berupa nyawa atau jiwa dan raga, serta harta, atau segala sesuatu (yang bernilai), termasuk keluarga. Sama dengan berjuang dan berperang, medannya adalah jalan Allah. Konteks ini mengandung pemahaman bahwa sesungguhnya perjuangan dan perang membutuhkan pengorbanan, dan bahwa pengorbanan itu sendiri merupakan sebuah jihad.

\section{Jihad sebagai Mati Syahid}

Sebagian siswa memahami jihad sebagai mati (syahid) itu sendiri, atau mati di dalam membela agama Allah. Dengan demikian, taruhan jihad adalah mati. Hal itu dapat dilihat pada statemen berikut ini: 
Tabel 4 : Pemaknaan Jihad sebagai Mati Syahid

\begin{tabular}{|c|l|}
\hline NO & \multicolumn{1}{|c|}{ KONSTRUKSI MAKNA JIHAD } \\
\hline 1 & Mati dalam racmbela agama Allah \\
\hline 2 & Wafat raembela agama, tanah air, bangsa, serta keluarga, di jalan Allah \\
\hline 3 & Meninggal karena membela kebenaran \\
\hline 4 & Seorangyang wafat derri membeia ajaran Allah Swt \\
\hline
\end{tabular}

\section{Jihad Sebagai Pembelaan Agama}

Kebanyakan konsep berjuang, berperang, dan berkorban di jalan Allah dikaitkan dengan tujuan membela agama Allah. Jadi bersifat defensif. Hanya sebagai kecil yang bermakna agresif dalam berjuang dan berperang sekalipun. Itulah sebabnya, trend penting pemaknaan jihad adalah membela Islam itu sendiri dengan berbagai kata semacamnya sebagai tanda. Selain membela juga mempertahankan, dua konsep yang digunakan untuk membangun mekanisme pertahanan diri (self defense mechanism) kaum muslimin menurut versi siswa. Tabel berikut ini menunjukkan bentuk pemaknaanjihad dengan pembelaan Islam.

Tabel 5: Pemaknaan Jihad sebagai Pembelaan Islam

\begin{tabular}{|c|l|}
\hline NO & \multicolumn{1}{|c|}{ KONSTRUKSI MAKNA JIHAD } \\
\hline 1 & Membela agama Islam sampai titikdarah penghabisan \\
\hline 2 & Membela kebenaran di jalan Allah \\
\hline 3 & Membela kebenaran di jalan Allah dengan mengorbankan harta dan jiwa \\
\hline 4 & Membela kebenaran di jalan Allah, menjalankanperaturan Allah \\
\hline 5 & $\begin{array}{l}\text { Melakukan pembelaan terhadap agama yang ia yakini saat ini, tanpa suatu kekerasan sesama } \\
\text { pemeluk agama lain dan sesuai ridho Allah SWT }\end{array}$ \\
\hline 6 & Membela aqidah agama Islam \\
\hline 7 & Membela agama dari tindakan agama lain \\
\hline 8 & Orang yang memberikan scluruh hidupnya untuk membela Allah \\
\hline 12 & $\begin{array}{l}\text { Merelakan diri atau mengabdikan diri kepada Allah swt apapun yang terjadi demi membela } \\
\text { umat Islam dalam bentuk apapun, sekalipun mempertambkan nyawa. }\end{array}$ \\
\hline 14 & Membela Islam sampai titik darah penghabisan \\
\hline 15 & $\begin{array}{l}\text { Membela kepenungan Islam, tidak hanya dengan berperang, tapi juga dalam menjalankan } \\
\text { kehidupan ini. }\end{array}$ \\
\hline 16 & Membela kebenaran Islam \\
\hline 18 & Membela apa yang benar menurut Islam \\
\hline
\end{tabular}

Pembelaan agama merupakan tanda paling umuni untuk meinaknai jihad baik langsung maupun tidak. Tanda yang langsung adalah seperti konstruksi jihad pada tabel 5; sementara tanda yang tidak langsung dapat dilihat pada tujuan dilaksanakannya perjuangan dan perang, dan pengorbanan yaitu dalam rangka membela agama Allah (tabel 1 dan 2, dan 3). Sasaran pembelaan adalah kebenaran Islam, kepentingan Islam, membela umat Islam, membela aqidah, membela Allah. Tingkat pembelaan sampai kepada titik darah penghabisan 
atau dengan nyawa sebagai taruhannya sampai kepada pembelaan tanpa kekerasan terhadap pemeluk agama lain.

\section{Jihad sebagai Kiprah Umum di Jalan Allah}

Ada sejumlah siswa yang memaknai jihad dengan konsep-konsep yang lebih umum dan inklusif, dengan tanda-tanda : usaha, sesuatu yang dikerjakan, pekerjaan dan sebagainya.

Dalam tabel berikut ini sejumlah konstruksi pemaknaan maknajihad dalam tanda yang lebih umum seperti berikut ini:

Tabel 6 : Pemaknaan Jihad secara Inklusif

\begin{tabular}{|c|l|}
\hline $\begin{array}{c}\text { NO } \\
1\end{array}$ & KONSTRUKSI MAKNA JIHAD \\
\hline 2 & Sesuatu yang dikerjakan semata-mata karena Allah. \\
\hline 3 & Suatu pekerjaan yang dilakukan demi mendapat keridhaan Allah \\
\hline 4 & $\begin{array}{l}\text { Menegakkan kebenaran di jalan Allah dengan melaksanakan yang diperintahkan dan menjauhi } \\
\text { yang dilarang. }\end{array}$ \\
\hline 5 & Hamba Allah yang senantiasa mengikuti perintah Allah dan menjauhi larangan Allah. \\
\hline 6 & Sesuatu yang bila dikerjakan pahalanya akan sangat besar di mata Allah \\
\hline 7 & Membawa nama Islam selama benar caranya dan di jalur yang benar \\
\hline 8 & Orang yg menegakkan agama Allah \\
\hline 9 & Menyebarkan agama Islam sesuai kaidah-kaidah yang ada dalam Alqur'an \\
\hline 10 & $\begin{array}{l}\text { Bersungguh-sungguh melakukan sesuatu, baik perang demi Islam maupun pekerjaan pekerjaan } \\
\text { di jalan Allah bahkan mengorbankan harta, benda, jiwa, dan raga. }\end{array}$ \\
\hline 11 & Dalam melakukan perbuatan diawali demgan niat karena Allah \\
\hline 12 & Melakukan suatu perbuatan atas nama Allah \\
\hline 13 & $\begin{array}{l}\text { Melakukan perintah Allah dan selalu beribadah kepadaNya sesuai dengan perintahnya dan } \\
\text { menjauhi larangannya. Bukan hanya berperang saja yangdinamakan jihad. }\end{array}$ \\
\hline 14 & Melakukan suatu perbuatan karena Allah \\
\hline 15 & Melakukan pekerjaan baik yang mengorbankan nyawa atau pun tidak dijalan Allah. \\
\hline 16 & $\begin{array}{l}\text { Memerangi diri sendiri agar tidak berbuat sesuatu yang dilarang ,oleh Allah swt dengan } \\
\text { melaksanakan ibadah sebaik-baiknya }\end{array}$ \\
\hline 17 & \begin{tabular}{l} 
Melawan hawa nafsu, contoh puasa atau pun bisa disebut melawan musuh Allah \\
\hline
\end{tabular} \\
\hline
\end{tabular}

Tanda-tanda yang mengandung maknajihad diwakili oleh konsep melawan hawa nafsu, memerangi diri sendiri, melakukan pekerjaan, perbuatan, melakukan perintah Allah dan menjauhi larangannya. Selain itu terdapat konsep bersungguhsungguh dalam pekerjaan, menyebarkan Islam, membawakan nama Islam secara benar, usaha yang diridlai Allah.

Meski jumlahnya tidak sebesar yang memaknai jihad dengan cara yang lainnya, pemaknaan yangterakhir ini mewakili maknajihadyang lebih luas dan kontekstual sesuai dengan kondisi dan tantangan umat Islam sekarang ini : kebodohan, kemiskinan, dan keterbelakangan. 
Konstruksi pemaknaan tentang jihad dirumuskan dengan kalimat yang berbeda tetapi makna yang relatif sama, dengan merujuk kepada penggunaan konsep tertentu sebagai kata-kata kunci seperti berjuang, berperang, berkorban, mati dijalan Allah, dalam rangka membela agama Islam mendominasi konstruksi pemaknaan siswa tentang jihad. Meski demikian, sejumlah siswajuga dapat memahami dalam pengertiannya yang lebih luas dan inklusif sebagai usaha di jalan Allah.

Deskripsi tentang pemaknaan jihad dengan penggunaan bahasa membawa kepada kategori inklusif untuk pemaknaan jihad sebagai usaha sungguh-sungguh dalam kebaikan; fundamental is untuk kategori berjuang dan membela, dan ekstrim untuk kategori perang dan mati syahid. Selanjutnya kategori fundamentalis dan ekstrim lebih disederhanakan dengan konsep puritanisme dan kategori inklusif digolongkan ke pandangan moderat, meminjam tipologi El-Fadl.

Ada fenomena pemahaman jihad yang terkesan fundamentalis sampai ekstrim. Sebanyak 44 persen siswa yang pemahaman tentang ihad berkonotasi fundamentalis bahkan 26 persen lainnya mengarah ke ekstrim. Hanya 13 persen yang dapat dikategorikan sebagai inklusif atau moderat. Kecenderungan puritanisme, dengan demikian, amat kuat di kalangan siswa. Iklim mikro keberagamaan komunitas muslim tersebut boleh jadi berpengaruh pada pandangan warganya. Ternate pernah mengalami suasana konflik bernuansa agama yang tentu saja berpengaruh baik secara psikologis maupun sosial.

Ada korelasi signifikan antara latar belakang sekolah (unggulan dan biasa) $(\mathrm{P}=0.012>0.05)$ dan latar belakang pendidikan orang tua $(\mathrm{P}=0,019>0,05)$ dengan pamaknaan tentangjihad. Siswa sekolah non-unggulan dan dengan orang tua berpendidikan relatif rendah cenderung lebih puritan.

Meski kecenderungan kuat ke arah puritanisme terjadi, namun sikap tersebut tidak ada hubungan sama sekali dengan penggunaan kekerasan atas nama agama. Bahkan siswa menolak perilaku radikalisme yang mengatasnamakan agama,

Sebanyak 84 persen responden memandang kekerasan bukanlah bagian dari penyelesaian masalah agama. Hal ini diekspresikan lewat sikap yang menunjukkan sebesar 41 persen dari mereka menyatakan tidak setuju, dan 29 persen menyatakan sangat tidak setuju sementara 17 persen lainnya kurang setuju. Terdapat sejumlah 16 persen responden yang menyatakan sikap persetujuan terhadap kekerasan atas nama agama. Ini merupakan titik balik dari pola penyelesaian masalah dengan kekerasan oleh kelompok agama tertentu 
ke arah kebutuhan liidup secara lebih aman dan damai dan lebih mementingkan pendekatan dakwah secara luas. Terhadap penganut aliran sesat, misalnya, siswa cenderung ke arah penyelesaian melalui jalur pembinaan (75 persen), daripada dengan cara lainnya, termasuk pembubaran.

Selain tidak berkorelasi dengan pandangan tentang kekerasan atas nama agama, pendangan jihadjuga tidak berkorelasi dengan referensi siswa belajar agama. Dalam penelitian ini, ditemukan bahwa siswa lebih banyak belajar agama ke guru agama di sekolah (36 persen), orang tua di rumah (21 persen), bukubuku agama (18 persen), belajar ke semua sumber tersebut. termasuk senior dalam organisasi dan tv (13 persen).

Meski guru agama banyak dijadikan referensi oleh siswa, materi jihad sendiri tidak termuat dalam sillabi mata ajar agama, sesuatu yang menjadi acuan guru untuk mengajar. Begitu pula halnya dengan buku-buku bacaan, tidak ditemukan yang memuat pembahasan jihad secara konprehensif yang dapat dijadikan pegangan bagi siswa. Referensi buku agama yang dibaca banyak terkait dengan buku tentang berita eskatologis, ibadah, novel islami, tokoh-tokoh dalam sejarah Islam sampai pacaran ala Islami, dan buku provokatif, seperti aliran-aliran sesat di Indonesia. Penulis tidak menemukan akses siswa kepada kajian yang lebih mencerahkan mengenai jihad dan tema-tema sosial yang lebih konstruktifuntuk pembangunan tatanan kehidupan lebih aman, damai, dan sejahtera. Boleh jadi tingkat ketertarikan dan kebutuhan siswa belum sampai ke sana. Jika demikian halnya, maka pemaknaan siswa mengenai jihad lebih merupakan hasil konstruksi sosial secara umum.

\section{DISKUSI TEORITIS}

Temuan penting dalam penelitian ini adalah kuatnya arus pemaknaanjihad sebagai perjuangan. pengorbanan, perang, mati syahid dan pembelaan agama. Hanya sebagian kecil siswa yang memberikan makna jihad sebagai sebuah usaha sungguh-sunguh dalam setiap kebaikan dalam medan kehidupan pada umumnya. Pemaknaan seperti itu tidak muncul begitu saja, melainkan terkait dengan konstruksi masyarakat tentangjihad. Secara teoritis hubungan ini dapat dilihat dari perspektif agama dan pembangunan dunia.

Menurut Berger, setiap masyarat manusia adalah suatu usaha pembangunan dunia. Agama menempati suatu tempat tersendiri dalam usaha ini. Masyarakat adalah fenomena dialektik dalam pengertian bahwa masyarakat adalah suatu produk manusia yang akan selalu memberi tindak kepada produsernya. Proses dialektik fundamental dari masyarakat terdiri dari tiga 
momentum, atau langkah, yaitu eksternalisasi, obyektivasi, dan internaiisasi. Eksternalisasi adalah suatu pencurahan kedirian manusia secara terus-menerus ke dalam dunia, baik dalam aktivitas fisis maupun mentalnya. Obyektivasi adalah disandangnya produk-produk aktivitas itu (baik fisis maupun mental), suatu realitas yang berhadapan dengan para produsennya semula, dalam bentuk suatu kefaktaan yang eksternal terhadap para produsen itu sendiri. Internaiisasi adalah peresapan kembali realitas tersebut oleh manusia dan mentransformasikannya sekali lagi dari struktur-struktur dunia obyektif ke dalam struktur-struktur kesadaran subyektif. ${ }^{8}$

Setiap masyarakat yang terus berjalan dalam sejarah akan menghadapi masalah pengalihan makna-makna terobyektivasinya dari satu generasi ke generasi berikutnya. Masalah ini diselesaikan dengan cara sosialisasi, yaitu proses yang dipakai mendidik generasi baru untuk hidup sesuai dengan program-program kelembagaan masyarakat tersebut. Tentu saja sosialisasi secara psikologis dapat disebut sebagai suatu proses belajar. Generasi baru diperkenalkan pada makna-makna budaya, belajar ikut serta dalam tugastugas yang sudah ditetapkan dan menerima peran-peran selain menerima identitas-identitas yang membentuk struktur sosialnya. Namun sosialisasi memiliki suatu dimensi penting yang tidak sepenuhnya bisa dijelaskan hanya dengan berbicara mengenai proses belajar. Individu tidak hanya belajar mengenai makna-makna terobyektivasi tetapijuga menghubungkan diri dengan, dan dibentuk oleh, makna-makna tersebut. Dia menyerap makna-makna tersebut dan menjadikannya makna-maknanya sendiri. Dia menjadi tidak saja seorang yang memiliki makna-makna ini, tetapi juga seorang yang mewakili dan mengekspresikan makna-makna tersebut."

Keberhasilan sosialisasi tergantung pada adanya simetri antara dunia obyektif masyarakat dengan dunia subyektif individu. Jika kita membayangkan seorang individu yang tersosialisasi total, maka setiap makna yang secara obyektif terdapat dalam dunia sosial akan mempunyai makna analognya secara subyektif di dalam kesadaran individu itu sendiri. Sosialisasi total seperti itu secara empiris tidak akan ada dan secara teoretis tidak mungkin ada, walaupun barangkali ini hanya akibat dari keragaman biologis individu-individu. Namun terdapat tingkattingkat keberhasilan dalam sosialisasi. Sosialisasi yang berhasil akan memberikan suatu simetri obyektif/subyektif tingkattinggi, sementara kegagalan sosialisasi mengarah kepada berbagai tingkat asimetri. Jika sosialisasi itu tidak berhasil menginternalisasi, sekurang-kurangnya, makna yang paling penting dari suatu mayarakat tertentu, maka masyarakat tersebut menjadi sulit untuk dipelihara 
sebagai suatu usaha yang layak. Teratoma, masyarakat seperti itu tidak akan berada pada posisi untuk membentuk suatu tradisi yang akan menjamin kelestarian masyarakat itu sendiri. ${ }^{10}$

Berdasarkan teori pembangunan dunia tersebut maka pemaknaan terhadap jihad merupakan hasil dari eksternalisasi, obyektivasi, dan internalisasi siswasiswa sebagai anggota masyarakat. Siswa mencurahkan dirinya ke dalam dunia nyata dalam kehidupan sehari-hari (eksternalisasi) dan mendapati pemaknaan jihad dengan cara tertentu di dalam masyarakat (obyektivasi) dan selanjutnya siswa menyerap kembali makna-makna tersebut ke dalam kesadarannya (internalisasi). Maknajihad berlangsungmelalui media sosialisasi,yaitu proses yang dipakai mendidik generasi baru untuk hidup sesuai dengan program-program kelembagaan masyarakat dimana siswa berada. Akan tetapi penyerapan maknajihad tidak berlangsung secara deterministik mekanistik melainkan bersifat dialektik dalam waktu lama dimana ia sendiri jadi peserta. Maka, dalam penciptaan pemaknaan jihad, siswa tidak hanya menyerap dari masyarakat tetapi iajuga berfungsi sebagai co-produser penciptaan makna tersebut untuk dirinya dan dunia sosialnya. Pemaknaan jihad oleh siswa, dengan demikian, merupakan hasil dialektika yang secara sosial terbentuk dalam mekanisme yang rumit dan panjang. Pemaknaan yang terbentuk lewat konstruksi sosial kemungkinannya sebangun dengan pengertian teoritis dan normatif berdasar ajaran suci Islam dan tradisi Nabi, tetapijuga kemungkinan sebaliknya.

Demikianlah, maka menurut Jamal Albana, jihad, sejak dahulu sampai sekarang merupakan diskursus yang paling banyak disalahpahami. Bahkan di era modern ini, jihad menjadi wacanayang paling dizalimi, baik oleh kalangan pro maupun kontra syari'at, juga dizalimi di dalam dan di luar Islam. Kesalahpahaman ini timbul pertama dan terutama dari pencampuradukan antara jihad dan qital (perang), bahkan pendominasian prang atas jihad dan penyikapan jihad sebagai perang lebih dari yang semestinya."

Jamal Albana menilai hal itu sebagai kesalahan fatal, karena jihad tidak selalu beriringan dengan perang. Sebaliknya jihad selalu merupakan prinsip pokok sementara qital hanyalah aksidental yang mendesak dilakukan jika memang diperlukan. Dalam lintasan sejarah dan realitas, Rasul dan sahabatnya telah melakukan jihad di Makkah selama 13 tahun dengan menggunakan saranasarana jihad yang mengandung pendekatan hikmah, mauizah hasanah, kesabaran, dan militansi. Dengan jihad seperti itu fase ini telah berhasil menguatkan basis akidah dan keimanan. Penindasan demi penindasan yang 
dialami selama di Mekah dihadapi dengan jihad damai dan telah merupakan bangku sekolah efektif. Setelah kaum Muslimin hijrah ke Madinah barulah terbuka fase qital terbuka hanya sebagai pembelaan diri dan pembelaan akidah. Inilah menurut Albana kunci rahasia diksi 'agar tidak terjadi fitnah' yang sering disebut dalam ayat-ayat qital.

Deskripsi kedua fase tersebut menjelaskan bahwa fase jihad bersifat tetap dan berkesinambungan, sementara fase kedua (qital) hanyalah fase penyempurna dalam rangka menjamin kebebasan akidah dan menangkal serangan. Karenanya, jika kedua sebab itu tidak ada, maka qital pun tidak diperlukan lagi. Berbeda dengan jihad yang bersifat tetap dan senantiasa diperlukan.

Itulah sebabnya ayat-ayat tentang qital ditempatkan di tengah-tengah ayat lain agar ayat-ayat tersebut dikendalikan oleh siyaq (konteks) dan menuruti jejak ayatayat lain. Yang terpenting lagi, adanya tipologi darurat atas ayat-ayat qital di tengah tipologi imaniyyah-qalbiyyah, juga di tengah dunia kebaikan, perdamaian, dan keadilan yang diaspirasikan ayat-ayat Alquran secara umum. Pemahaman ayatayat qital tidak akan terbentuk kecual ijika kita menghad irkan Alquran secara utuh.

Albana melihat kesalahpahaman tentangjihad sebagai qital (perang) terjadi karena kalangan yang membahas diskursus ini lebih sering hanya mencuplik satu atau beberapa ayat, mengucilkannya dari konteksnya, menelanjanginya dari kondisi yang mengiringinya, dan terakhir memutuskan status hukumnya hanya berdasarkan satu atau beberapa ayat tersebut. Kesalahpahaman juga terjadi ketika pemahaman qital itu sendiri yang telah melampaui otoritas tujuan awalnya sebagai usaha menangkis serangan dan menolak fitnah (kekacauan) menjadi lebih luas lagi sebagai media penyebaran akidah. Islamisasi dunia dan usaha penyelamatannya dari jahiliyah modern sekaligus pengenalan hukum Tuhan. Ini merupakan perkembangan genting yang akan membuka pintu pelecehan terhadap kebebasan berakidah bagi pihak lain dan rentan menyeret kita pada dimensi ekstrimisme yang lebih jauh lagi. ${ }^{13}$

Di dalam Alquran terdapat alternatif-alternatif yang luas, lapang dan beragam, sehingga Alquran mampu eksis dan berkomunikasi dengan beragam perkembangan, juga beragam pemahaman. Setiap ayat memiliki kedudukan, munasabah, dan asbab (al-nuzul) sendiri-sendiri. Yang terpenting, setiap orang harus mengambil setiap ayat dari konteksnya, jugajangan sampai ada yang fanatis dengan kesimpulan akhir yang didapatkannya, atau sampai berasumsi bahwa hanya pendapatnyalah yang benar sementara yang lain salah. 
secara kuat untuk menghayati, membatinkan (menginternalisasi) dan mengamalkan ajaran yang telah difahami, dikuasai atau dimilikinya. Dengan demikian, pengajaran pendidikan agama dengan pendekatan ilmu-ilmu sosialpadajenjang pendidikan dasar dan menengahbelum tepat.

Ketiga, pendekatan perencanaan sosial (social planning approach). Dalam konteks penyelenggaraan pendidikan agama di negeri kita,pendekatan perencanaan sosial terakhir inilah yang dapat dianggap "paling tepat" untuk diterapkan. Pendekatan ini diorientasikan pada pemenuhan kebutuhan nyata masyarakat dalam rangka penataan kehidupan masyarakat yang lebih baik di masa depan. Bangsa Indonesia, dengan segenap ciri kemajemukannya, tampak cocok mengembangkan pendekatan perencanaan sosial dalam merealisasikan kebijakan penyelenggaraan pendidikan agama. Diharapkan, penerapan pendekatan ini, dapat mendorong siswa (peserta didik) untuk meresapi, menghayati, dan mengamalkan ajaran/materi agama yang diterimanya. Selain itu, pendekatan ini diharapkan dapat mengembangkan nilai-nilai multikultural, seperti menghormati, menghargai, dan toleran dengan pemeluk dan ajaran agama lain. 19

Eksternalisasi; obyektivasi, dan internalisasi nilai-nilai di sekolah memerlukan desain tersendiri, sehingga sekolah bukan saja merupakan sumber belajar kebaikan bagi anak-anak didik, tetapi juga pusat keunggulan budaya di dalam masyarakat.

\section{Kesimpulan}

1. Pemaknaan siswa tentang jihad pada daerah kasus didominasi oleh pandangan yang sempit dan lebih mengarah kepada pengertian qital. Hal itu dipahami dari penggunanan term-term makna jihad sebagai perjuangan, pengorbanan, perang, mati syahid dan pembelaan agama (Islam). Hal ini berbeda dengan prinsip jihad sebagaimana dipahami dari Alquran dan tradisi Nabi.

2. Tidak ada korelasi yang signifikan antara pemahaman jihad dengan sumber-sumber belajar siswa, termasuk sekolah. Hal ini dapat dipahami sebagai lemahnya peran sekolah dalam memberi pemahaman tentang ajaran Islam yang amat sentral tersebut. Pemahaman tentang jihad, dengan demikian, lebih ditentukan oleh konstruksi sosial.

3. Meski memiliki pandangan yang puritan tentang jihad, siswa ternyata menolak penyelesaian masalah dengan menggunakan kekerasan atas nama agama. Dengan kata lain, generasi muda Islam tersebut menolak radikalisme agama. Hal ini membawa peluang besar bagi internalisasi pemahaman jihad yang lebih inklusif dan moderat lewat pendidikan agama di sekolah. 
secara kuat untuk menghayati, membatinkan (menginternalisasi) dan mengamalkan ajaran yang telah difahami, dikuasai atau dimilikinya. Dengan demikian, pengajaran pendidikan agama dengan pendekatan ilmu-ilmu sosialpadajenjang pendidikan dasar dan menengahbelum tepat.

Ketiga, pendekatan perencanaan sosial (social planning approach). Dalam konteks penyelenggaraan pendidikan agama di negeri kita,pendekatan perencanaan sosial terakhir inilah yang dapat dianggap "paling tepat" untuk diterapkan. Pendekatan ini diorientasikan pada pemenuhan kebutuhan nyata masyarakat dalam rangka penataan kehidupan masyarakat yang lebih baik di masa depan. Bangsa Indonesia, dengan segenap ciri kemajemukannya, tampak cocok mengembangkan pendekatan perencanaan sosial dalam merealisasikan kebijakan penyelenggaraan pendidikan agama. Diharapkan, penerapan pendekatan ini, dapat mendorong siswa (peserta didik) untuk meresapi, menghayati, dan mengamalkan ajaran/materi agama yang diterimanya. Selain itu, pendekatan ini diharapkan dapat mengembangkan nilai-nilai multikultural, seperti menghormati, menghargai, dan toleran dengan pemeluk dan ajaran agama lain. 19

Eksternalisasi; obyektivasi, dan internaiisasi nilai-nilai di sekolah memerlukan desain tersendiri, sehingga sekolah bukan saja merupakan sumber belajar kebaikan bagi anak-anak didik, tetapi juga pusat keunggulan budaya di dalam masyarakat.

\section{Kesimpulan}

1. Pemaknaan siswa tentang jihad pada daerah kasus didominasi oleh pandangan yang sempit dan lebih mengarah kepada pengertian qital. Hal itu dipahami dari penggunanaan term-term makna jihad sebagai perjuangan, pengorbanan, perang, mati syahid dan pembelaan agama (Islam). Hal ini berbeda dengan prinsip jihad sebagaimana dipahami dari Alquran dan tradisi Nabi.

2. Tidak ada korelasi yang signifikan antara pemahaman jihad dengan sumber-sumber belajar siswa, termasuk sekolah. Hal ini dapat dipahami sebagai lemahnya peran sekolah dalam memberi pemahaman tentang ajaran Islam yang amat sentral tersebut. Pemahaman tentang jihad, dengan demikian, lebih ditentukan oleh konstruksi sosial.

3. Meski memiliki pandangan yang puritan tentang jihad, siswa ternyata menolak penyclesaian masalah dengan menggunakan kekerasan atas nama agama. Dengan kata lain, generasi muda Islam tersebut menolak radikalisme agama. Hal ini membawa peluang bes'ar bagi internaiisasi pemahaman jihad yang lebih inklusif dan moderat lewat pendidikan agama di sekolah. 


\section{Catatan Akhir:}

'Khaled Abou El Fadl, The Great Theft, Wrestling Islam From the Extremist (New York): Harpecollins Publisher 2007), p. 220.

Hbid

${ }^{3}$ Harian Tempo, tanggal 10 November 2008

'Ibid

${ }^{5}$ Kota Ternate Dalam Angka, 2007 (Badan Pusat Statistik Kota Ternate,2007) hi. 57.

${ }^{6}$ Benny H. Hoed, Semoitik dan Dinamika Sosial Budaya (Jakarta : Fakultas Ilmu Pengetahuan Budaya UI, 2008), hi. 89

'Departemen Pendidikan Nasional, Kamus Besar Bahasa Indonesia (Jakarta: Balai Pustaka, 2002), hi. 478.

"Peter L. Berger,Langit Suci, Agama sebagai Realitas Sosial (Jakarta : LP3ES, 1994), hi. 4

Hbid

">Ibid, hi 20.

"Jamal Albanna, Revolusi Sosial Islam (Pilar Media, Yokyakarta, 2005) hi. xx

"ibid., hl.xxi

"Ibid., hl.xxvi.

"Ibid,h\. 116

'Jamal Albana, Revolusi Sosial Islam (Pilar Media, Yokyakarta, 2005), hi. 25

"Ibid, hi. 74

"E1-Fadl, op.cit.,p. 221

"Ibid., p. 223.

${ }^{19}$ HM. Atho Mudzhar, Makalah disampaiakan Pada Pembukaan Workshop Penyelenggaraan Pendidikan Agama Kristen Di Sekolah, Tanggal 26 Mei 2008, Di STAKN Tana Toraja Sulawesi Selatan

\section{DAFTAR PUSTAKA}

Albana, Jamal. 2005. Revolusi Sosial Islam, Dekontruksi Jihad dalam Islam. Pilar Media. Yokyakarta

Berger, Peter L. 1994. Langit Suci, Agama sebagai Realitas Sosial. LP3ES. Jakarta.

Departemen Pendidikan Nasional.2002. Kamus Besar Bahasa Indonesia. Balai Pustaka. Jakarta

El Fadl, Khaled Abou.2005. The Great Theft, Wrestling Islam From The Extremist. Harper Collins. USA.

Hoed, Benny H. 2008. Semiotik dan Dinamika Sosial Budaya. Fakultas Ilmu

Pengetahuan Budaya UI Depok. Jakarta.

Kota Ternate Dalam Angka. 2007. Badan Pusat Statistik Kota Ternate. 